\title{
EVALUATION OF MALE INBRED LINES OF SUNFLOWER (Helianthus annuus L.) FOR RESISTANCE TO DROUGHT VIA CHLOROPHYLL FLUORESCENCE
}

\author{
Yalcin $K A Y A^{l^{*}}$, A. Suna BALKAN NALCAIYI ${ }^{2}$, Sekure CULHA ERDAL ${ }^{2}$, Ozlem ARSLAN ${ }^{3}$, Nuran \\ CICEK $^{2}$, Veli PEKCAN ${ }^{4}$, M. Ibrahim YILMAZ ${ }^{4}$, Goksel EVCI ${ }^{4}$, Yasemin EKMEKCI ${ }^{2}$ \\ ${ }^{1}$ Trakya University, Engineering Faculty, Genetic and Bioengineering Dept, Edirne, TURKEY \\ ${ }^{2}$ Hacettepe University, Science Faculty, Biology Dept, Ankara, TURKEY \\ ${ }^{3}$ Giresun University, Espiye Vocational School, Giresun, TURKEY \\ ${ }^{4}$ Trakya Agricultural Research Institute, Edirne, TURKEY \\ * Corresponding author: yalcinkaya22@gmail.com
}

Received: 05.05.2016

\begin{abstract}
Sunflower (Helianthus annuus L.) suffers from terminal drought accompanying with high temperature stress since it grows mainly in rain fed areas. Therefore, plant breeders try to improve more drought tolerant varieties and to screen their genetic materials for drought resistance. The present study was conducted to determine drought tolerance levels of sunflower male inbred lines developed by Trakya Agricultural Research Institute (TARI), Edirne, Turkey. Inbred lines grown under controlled environmental conditions were sorted by polyphasic chlorophyll $a$ fluorescence measurements. Drought stress applications were performed at three sunflower growth stages as R-3 (vegetative), R5-1 (head formation) and R-6 (milky seed). Based on applied different JIP-Test (analysis of O-J-I-P fluorescence transient) parameters such as Drought Factor index (-DFI) and Damage index (-DI), $70352 \mathrm{R}, 8129 \mathrm{R}, 0536 \mathrm{R}$ and $9947 \mathrm{R}$ restorer lines were found more drought tolerant than those of the other examined sunflower inbred lines, whereas TT $317 \mathrm{R}$ and TT $199 \mathrm{R}$ were determined as more drought sensitive than others. The drought tolerant inbred lines will be helpful to improve drought resistance in sunflower breeding programs.
\end{abstract}

Keywords: Helianthus annuus L., sunflower, drought tolerance, inbred lines, chlorophyll $a$ fluorescence, JIPtest

\section{INTRODUCTION}

Important prevalent biotic and abiotic stresses negatively affect the growth and development of plants. Thus, yield and seed quality decrease due to biotic and abiotic stresses. Abiotic stresses including drought, high temperatures, cold, salinity, deficiency and toxicity of plant nutrients are mainly responsible for yield losses on the crop plants in the world (Awais et al., 2015; Ghaffari et al., 2012; Gül and Kara, 2015; Güney et al., 2012; Shehzad and Maqsood, 2015; Y1ldirım et al., 2010). Drought together with high temperature are thought to be the most important abiotic stresses in arable lands because of global warming (Toker 2009 and 2014; Sezener et al. 2015). Plants in the arable lands mainly suffer from (i) terminal drought, increasing towards the end of the growing season; and (ii) intermittent or transient drought, breaking rainfall or insufficient rains during the growing season (Toker and Mutlu, 2011).

Sunflower (Helianthus annuus L.) is the main source of unsaturated vegetable oil and one of the most important agricultural crops in the world (Baloglu et al., 2012; Gholinezhad et al., 2015; Langeroodi et al., 2015; Kaya et al., 2015). Sunflower is the $3^{\text {rd }}$ oil crop in the world cultivating in over 25 million ha with over 40 million tones production. Turkey takes place in the top ten countries in the world with having 605.000 ha planting areas, 1,523 million tones production and $24,976 \mathrm{Hg} / \mathrm{Ha}$ yield (FAOSTAT, 2013). It is cultivated widely in drylands and rainfed areas. Drought stress is common factor affecting adversely sunflower plants growth resulting in seed and oil yield and quality losses (Karadoğan et al., 2009; Ghaffari et al., 2012; Kaya, 2014; Kaya et al., 2016). Although sunflower is thought to be more tolerant/resistant (Howell et al., 2015), especially some vegetation stages such as germination, flowering and milky seed are known as the most critical stages for experiencing water stress. Despite of its deep roots, depleting more available soil water, still the high temperatures in summer, especially during the most critical vegetation stages, affect sunflower plants mostly by limiting the water supply to the roots and increasing the transpiration rate (Karam et al., 2007, Iqbal 
et al., 2008). Therefore, plant breeders should realize the physiological mechanisms of drought stress and develop better selection and breeding strategies to enhance crop yields (Richards, 2006; Ceccarelli et al., 2007).

Photosynthesis is the most important metabolic process in the plant development and its performance is greatly influenced under drought stress in multidimensional ways such as reduction in leaves expansion, decreases in $\mathrm{CO}_{2}$ diffusion to the chloroplast, impairment of photosynthetic apparatus and expedition of leaf senescence (Farooq et al., 2009; Pinheiro and Chaves, 2011; Hasanuzzaman et al., 2014). Water stress induces a diminution of photosynthetic rate and an increase in the dissipation of absorbed energy through non-radiative processes (Faraloni et al., 2011). Under drought conditions, photo system II (PSII) is more sensitive than photo system I (PSI) (Deng et al., 2003); therefore, PSII has a key role to analyze changes that occur in photosynthesis (Baker, 1991). Chlorophyll a fluorescence measurement is a non-invasive method for determining PSII activity and is a commonly used technique (Murchie and Lawson, 2013) in the greenhouse and field conditions. For evaluating the photosynthetic performance, chlorophyll a fluorescence kinetics can be considered as a biosensor tool. The analysis of the fast chlorophyll fluorescence induction curve (OJIP) kinetics, called JIP test, quantifies the in vivo energy fluxes passing through the reaction centers and photo systems (Strasser and Strasser, 1995; Strasser et al., 2000), as well it includes different steps and phases of the redox states of PSII and correlates the phases with the efficiencies of electron transfer between PSII and PSI and to the end of electron acceptor (Strasser et al., 2004, Öz et al., 2014).

The objective of the current study is to determine the plant responses to drought stress in different critical sunflower growth stages in male plants of sunflower, performing polyphasic chlorophyll $a$ fluorescence transients' measurements and further applying of JIP-Test.

\section{MATERIALS AND METHODS}

\section{Materials}

Initially, drought experiments were conducted with 50 inbred sunflower (Helianthus annuus L.) lines but unfortunately only twenty-two lines remained alive. Therefore, all the obtained results and further discussions are in relation to these twenty-two lines only, which are given in Table 1. 22 male sunflower inbred lines were used and sown, originated from different genetic sources and developed in National Sunflower project conducted by TARI.

Table 1. The sown sunflower male inbred lines used in the study.

\begin{tabular}{lll}
\hline$\#$ & Code & Pedigree \\
\hline 1 & $70352 \mathrm{R}$ & RF-801 X INCR-3 \\
2 & $8129 \mathrm{R}$ & ST-93 OR-113 \\
3 & $0536 \mathrm{R}$ & TTAE Gene Pool \\
4 & $9947 \mathrm{R}$ & SG Resistance Sources-2 \\
5 & $6973 \mathrm{R}$ & ND-RLOS X INCR-3 \\
6 & $9993 \mathrm{R}$ & TTAE Gene Pool \\
7 & CL 217 R & TTAE Gene Pool \\
8 & TT 321 R & TTAE Gene Pool \\
9 & $7887-1 \mathrm{R}$ & ST-92 OR-101 \\
10 & $9979 \mathrm{R}$ & Vnimik Mutation B9 B2 X RHA 437 \\
11 & $62301 \mathrm{R}$ & TTAE Gene Pool \\
12 & TT 214 R & TTAE Gene Pool \\
13 & TT 212 R & 0536 R x TTAE Gene Pool \\
14 & $010018 \mathrm{R}$ & TTAE Gene Pool \\
15 & TT 119 R & TTAE Gene Pool \\
16 & $9997-7 \mathrm{R}$ & TTAE Gene Pool \\
17 & $9987 \mathrm{R}$ & RHA 437 x Vnimik Mutation B9 \\
18 & $25712 \mathrm{R}$ & PU-4014 \\
19 & $01001 \mathrm{R}$ & TTAE Gene Pool \\
20 & TT 216 R & TTAE Gene Pool \\
21 & TT 199 R & (RHA 438x0536R)X((0536RX(25712RX6973R))X7794R) \\
22 & TT 317 R & Vnimik Mutation \\
\hline & &
\end{tabular}

\section{Drought Tolerance Tests}

Tolerance tests for 22 male inbred lines were conducted in controlled conditions under isolated cages. There were five plants in each row and the distance between rows was $70 \mathrm{~cm}$ and in rows was $30 \mathrm{~cm}$. Trials were planted by hand on May $29^{\text {th }}$ and plants were harvested and threshed by hand on September $24^{\text {th }}, 2014$. The major yield traits and also phenological observations for the male inbred lines of sunflower were measured and evaluated in the study. Stress group 1, 2 and 3 were set up on 23.06.2014, 22.07.2014 and 04.08.2014 respectively, covered with rain shelters over plants.

For the needs of the field experiment, there were set one control group and three stress groups. 
Control group: In this group, all plants were sown under natural conditions. Chlorophyll $a$ fluorescence data was measured on July $22^{\text {th }}$, on August $6^{\text {th }}$ and on August $20^{\text {th }}$. The water requirements for all plants were supplied by drip irrigation, when field capacity was reduced to $50 \%$. The amount of rainfall during the course of the experiment was as follows: $50 \mathrm{~mm}$ on June $10^{\text {th }}, 70 \mathrm{~mm}$ on June $25^{\text {th }}, 65$ $\mathrm{mm}$ on July $10^{\text {th }}, 40 \mathrm{~mm}$ on July $25^{\text {th }}, 75 \mathrm{~mm}$ on August $10^{\text {th }}, 60 \mathrm{~mm}$ on August $18^{\text {th }}, 60 \mathrm{~mm}$ on August $28^{\text {th }}$, respectively.

Stress group 1 (S1) (at vegetative stage, when plants were $50 \mathrm{~cm}$ ):_in the first stress group, the plants were covered with rain shelters on the $28^{\text {th }}$ day after the planting. Later, three consecutive chlorophyll $a$ fluorescence measurements were done: on the $26^{\text {th }}$ day (S1-1 stress group), on the $41^{\text {st }}$ day (S1-2 stress group) and on the $83^{\text {th }}$ day, (S1-3 stress group) after applying drought stress. Due to severe drought conditions, there were no suitable data for S1-3 stress group, so this group was not considered in the study. All sub stress groups were compared with the control plot that was irrigated and no drought stress was applied.

Stress group 2 (S2) (at bud development stage): plants from the second stress group were covered with rain shelters on the $54^{\text {th }}$ day after the planting. The first chlorophyll fluorescence measurement was done on the $54^{\text {th }}$ day, i.e. just before covering of the plants. This measurement point was marked as S2-1. S2-1 stress group plants were left unirrigated in natural conditions before the time of being covered with rain shelters. Further, after applying drought stress for 15 days (S2-2 stress group) and for 29 days (S2-3 stress group), respectively, two additional measurements were done. All sub stress groups were compared with the control plot which was irrigated and no drought stress was applied.

Stress group 3 (S3) (at the milky seed stage): In the third stress group, the first measurement (S3-1 stress group) was done on the $54^{\text {th }}$ day after planting. Anyway, the measurements data obtained from S3-1 stress group weren't considered in the study due to the fact that this measurement point coincides with S2-1 record point. Plants from the milky seed stage were covered with rain shelters on the $69^{\text {th }}$ day after planting. At that moment, it was performed the second chlorophyll fluorescence measurement, representing the obtained data for S3-2 stress group. Similarly, to S2-1 stress group plants, till the moment of measurements, S3-2 plants were growing in natural conditions, without additional irrigation. The third measurement (S3-3 stress group) was recorded after 14 days of drought stress. All sub stress groups were compared with the control plot where plants were irrigated and no drought stress was applied.

\section{Chlorophyll a Fluorescence Measurements}

Chlorophyll $a$ fluorescence measurements were performed by a portable non-modulated fluorimeter HandyPEA (Hansatech Instruments Ltd., King's Lynn Norfolk, PE 4 NE, UK) at the R3, R5-1 and R6 vegetative stages. The special leaf instrument clips were attached to the $6-8^{\text {th }}$ leaves from bottom of plants of control and inbred lines in different stress groups. After the leaves were darkadapted at least $30 \mathrm{~min}$, measurements were carried out at $4 \mathrm{~mm}^{2}$ leaf area. Dark-adapted leaves were illuminated with $600 \mathrm{Wm}^{-2}$ red light $\left(3000 \mu \mathrm{molm}^{-2} \mathrm{~s}^{-1}\right.$, enough light intensity to be closed of all PSII reaction centers) supplying from 3 diodes and over $700 \mathrm{~nm}$ fluorescence was recorded for one hour at 12-byte resolution.

The rapid florescence kinetics (minimum fluorescence, $\mathrm{F}_{0}$; maximum fluorescence, $\mathrm{F}_{\mathrm{M}}$ ) was recorded from $10 \mu \mathrm{s}$ to 1 hour and the recorded signal at $20 \mu \mathrm{s}$ was accepted as minimum fluorescence $\left(\mathrm{F}_{0}\right)$ (Strasser and Strasser, 1995). The recorded fluorescence transient OJIP data were analyzed according to JIP-Test using Biolyzer HP3 program obtaining information from photosynthesis process (Strasser and Strasser, 1995). The terms and formulae used in the JIP-test and analyzed in this study are presented in Table 2. The photosynthetic states of sunflower inbred lines were determined performing these tests. Damage index and Drought factor index (DFI) were calculated by utilizing $\mathrm{PI}_{\mathrm{abs}}$ and $\mathrm{PI}_{\text {total }}$. Total Performance Index and Drought Factor Index are widely used indicators to screen and classify of drought tolerance in plants. Therefore, sunflower inbred lines were evaluated and categorized based on these two key indicators in this study.

Damage Index (\%): (Drought Stress - Control) / [1 (Control/100)] X 100

This index was calculated from model based on Glerum (1985).

Drought Factor Index: DFI $=\log A+2 \log B$

$A$ : The average relative PI for first drought stress period

$B$ : The average relative PI for second drought stress period The average relative PI: Drought stress PI / Control PI (Strauss et al. 2006; Oukarroum et al., 2007) 
Table 2. The terms and formulae used in the JIP-test and assessed in this study (Strasser et al. 2010).

\begin{tabular}{|c|c|}
\hline $\begin{array}{c}\text { Fluorescence } \\
\text { parameters }\end{array}$ & Formula/Explanation \\
\hline $\mathrm{ABS} / \mathrm{RC}$ & $\begin{array}{l}\left(1-\gamma_{R C}\right) / \gamma_{R C} \\
\text { Absorption flux (of antenna Chls) per reaction center }(\mathrm{RC}) \text {. It represents the used total absorption } \\
\text { of PSII antenna chlorophylls per active RC. i.e. of the average antenna size (Strasser et al., 2000) }\end{array}$ \\
\hline $\mathrm{DI}_{0} / \mathrm{RC}$ & $\begin{array}{l}\text { ABS/RC }-\mathrm{TRo} / \mathrm{RC} \\
{\left[\mathrm{TRo} / \mathrm{RC}=\mathrm{M}_{0} \mathrm{X}(1 / \mathrm{VJ}) \text {, Trapping flux (leading to QA reduction) per } \mathrm{RC}\right]} \\
{\left[\mathrm{M}_{0}=4 \mathrm{X}\left(\mathrm{F}_{300}-\mathrm{F}_{0}\right) /\left(\mathrm{F}_{\mathrm{M}}-\mathrm{F}_{0}\right) \text {, approximated initial slope (in ms-1) of the fluorescence transient } \mathrm{V}\right.} \\
=\mathrm{f}(\mathrm{t})] \\
\text { Dissipated energy flux per RC. It is the rate of distribution of non-dissipating energy by } \mathrm{RC} \text { (not } \\
\text { directing electron transportation) in the total active energy of } \mathrm{RC}\end{array}$ \\
\hline $\mathrm{F}_{\mathrm{V}} / \mathrm{F}_{\mathrm{M}}$ & $\begin{array}{l}\varphi_{P o}\left(=1-F_{0} / F_{M}=F_{V} / F_{M}\right) \\
\text { It represents the efficiency by which an absorbed photon will be trapped by PS II reaction centers. } \\
F_{\mathrm{o}} \text { is the initial minimal value (when all reaction centers were open and all } Q_{A} \text { oxidized) and } F_{M} \text { is } \\
\text { the maximal level (when all reaction centers were closed and all } Q_{A} \text { reduced) (Oukarroum et al., } \\
2015)\end{array}$ \\
\hline $\mathrm{PI}_{\mathrm{abs}}$ & $\begin{array}{l}{[\gamma \mathrm{RC} /(1-\gamma \mathrm{RC})] \mathrm{X}\left[\varphi_{\mathrm{Po}} /\left(1-\varphi_{\mathrm{Po}}\right)\right] \mathrm{X}[\psi \mathrm{o} /(1-\psi \mathrm{o})]} \\
{\left[\psi \mathrm{O}=\mathrm{ET}_{0} / \mathrm{TR}_{0}=1-\mathrm{V}_{\mathrm{J}}, \text { probability that a trapped exciton moves an electron into the electron }\right.} \\
\left.\text { transport chain beyond } \mathrm{Q}_{\mathrm{A}}^{-}\right] \\
\text {Performance index (potential) for energy conservation from exciton to the reduction of intersystem } \\
\text { electron acceptors }\end{array}$ \\
\hline $\mathrm{PI}_{\text {total }}$ & $\begin{array}{l}\left(\mathrm{PI}_{\mathrm{abs}}\right) \mathrm{X}[(\delta \mathrm{Ro} /(1-\delta \mathrm{Ro})] \\
{\left[\left(\delta \mathrm{Ro}=\mathrm{RE}_{0} / \mathrm{ET}_{0}=\left(1-\mathrm{V}_{\mathrm{I}}\right) /\left(1-\mathrm{V}_{\mathrm{J}}\right) \text {, the efficiency with which an electron can move from the reduced }\right.\right.} \\
\text { intersystem } \\
\text { electron acceptors to the PSI end final electron acceptors }] \\
\text { Performance index (potential) for energy conservation from exciton to the reduction of PSI end } \\
\text { acceptors }\end{array}$ \\
\hline
\end{tabular}

The inbred lines were categorized giving them points, corresponding to calculations performed for these parameters $\left(\mathrm{PI}_{\mathrm{abs}}\right.$ and $\left.\mathrm{PI}_{\text {total }}\right)$. The genotype having the highest point value has been determined as the most drought tolerant one.

\section{Statistical Analyses}

The experiments were carried out in a completely randomized block design with three replicates from each inbred line. Five replicates of each chlorophyll measurement were performed in each plant. Differences among groups and genotypes were calculated using SPSS statistical program. Statistical analysis of variance (ANOVA) of the data was performed and compared using LSD test at the $5 \%$ level.

\section{RESULTS AND DISCUSSION}

Drought stress is one of the main environmental stress factors adversely affecting the growth, development and yield of many field crops (Toker and Mutlu, 2011). The effects of water stress on some parameters of chlorophyll $a$ fluorescence were investigated in sunflower inbred lines at three different growth stages, i.e. vegetative, head formation and milky stages which play critical role in the formation of sunflower yield. The significant differences were detected in JIP-Test parameters in relation to photochemical activities of sunflower restorer lines analysed in the current study.

\section{Changes in $A B S / R C$ values of lines at vegetative, head formation and milky stages}

There was no significant change in ABS/RC parameter, which represents the used total absorption of PSII antenna chlorophylls per active RC. i.e of the average antenna size (Strasser et al., 2000) among the tested sunflower genotypes in terms of the effect of drought stress applied on the vegetative stage. The changes in the rate of active and/or inactive $\mathrm{RC}$ affect directly the ABS/RC parameter. Sunflower inbred lines were subjected to drought stress for 26 and 41 days after emergence (28 days-plants), designated respectively as S1-1 and S1-2 stress condition. It was determined that $\mathrm{ABS} / \mathrm{RC}$ values decreased significantly at S1-2 comparing with S1-1, except for 25712R and TT317R inbred lines (Figure 1a). When comparing every drought stress treatment with controls in all genotypes was observed significant increase in the ABS/RC values at the S1-1 compared to their control. Similarly, the increase in ABS/RC value in all sunflower inbred lines at S1-2, compared to their control, was also significant, except for $9987 \mathrm{R}$ inbred line.

The changes in ABS/RC values of sunflower inbred lines exposed to drought were found to be statistically significant in most of the genotypes. When comparing one to one the three stress groups there were determined significant changes for ABS/RC antenna sizes in most of the genotypes (Figure 2a) except for 01001R, 6973R and CL217R inbred lines when compared S2-3 to S2-2; 62301R, 9987R, 9997-7R and TT214R genotypes 
comparing S2-3 with S2-1; 25712R, 9993R and TT321R male lines in S2-2 in comparison to S2-1. While compared each stress group with the controls, the results showed statistically significant increase in the ABS/RC values for the sunflower inbred lines except $0536 \mathrm{R}$ and $6973 \mathrm{R}$ for $\mathrm{S} 2$ 2 and $70352 \mathrm{R}, 7887-1 \mathrm{R}, 9979 \mathrm{R}, 9987 \mathrm{R}, 9997-7 \mathrm{R}$, TT119R, TT212R, TT214R and CL217R male lines for S21 and S2-3 application

Among the plants under drought stress at at the milky seed stage was observed decrease in ABS/RC values for 010018R, 70352R, 9987R, TT317R and TT321R restorer lines for S3-3 compared to S3-2 stress group (Figure 3a). When compared each stress group with the controls, significant increases in ABS/RC values were detected in 0536R, 010018R, 25712R, 6973 R, 70352R, 7887-1R, 8129 R, 9947R, 9979R, 9987R, 9993 R, 9997-7R, TT119 R, TT199R, TT214 R, TT216R, TT317 R and TT321R inbred lines for S3-2 and 0536R, 010018R, 25712R, 62301 R, 6973 R, 70352R, 7887-1R, 9947R, 9979R, 9987R, 9993 R, 9997-7R, TT119 R, TT199R, TT212 R, TT214R, TT216R, TT321 R and CL217R for S3-3. The changes in the rate of active / inactive $\mathrm{RC}$ affect directly to the $\mathrm{ABS} / \mathrm{RC}$ parameter. Increase in this parameter might represent the decrease of the fraction of active RCs. This result is similar to previous studies (Kalaji et al., 2014; Oukarroum et al., 2015).

\section{Changes in DIo/RC values of lines at vegetative, head formation and milky stages}

The changes in the $\mathrm{DI}_{0} / \mathrm{RC}$ values, which represent dissipation or energy loss per active reaction centre, measured at vegetative stage of sunflower inbred lines under drought stress were found statistically significant $\mathrm{DI}_{0} / \mathrm{RC}$ value of inbred lines under stress treatment decreased significantly at S1-2 level comparing with S1-1 except TT317R. Furthermore, the highest decrease on this value was observed in $01001 \mathrm{R}, 9947 \mathrm{R}$ and TT321 R at S11 level and 25712R, TT199 R and TT321 R at S1-2 level to the control (Figure 1b). When compared with their controls, the increases were found significant at S1-1 and at S1-2 stress treatments (except 9987R for S1-2).

The changes in $\mathrm{DI}_{0} / \mathrm{RC}$ values measured for the three stress groups - S2-1, S2-2 and S2- 3 at the head formation stage of sunflower inbred lines were found statistically nonsignificant except 01001 R, 6973 R, 8129 R, 9979 R, 9997 7 R, TT199 R, TT 212 R and TT 214 R when compared S22 with S2-1; 0536R, 010018 R, 25712R, 70352 R, $7787-$ 1R, 9947 R, 9979R, 9987 R, 9993 R, 9997-7 R, TT119 R, TT199 R, TT212 R, TT216R, TT317R and TT321 R restorer lines comparing S2-3 with S2-2; and 0536R, 010018 R, 25712 R, 7887-1 R, 9979 R, 9993 R, TT119 R, TT 199 R, TT212 R, TT $216 \mathrm{R}$ and TT321 R restorer lines for S2-3 and S2-1 (Figure 2b). When compared each stress group with the controls; there were no significant differences among the studied genotypes, based on $\mathrm{DI}_{0} / \mathrm{RC}$ values, except 010018 R, $62301 \mathrm{R}, 6973 \mathrm{R}, 8129 \mathrm{R}, 9947$ R, 9979 R, 9993 R, $9997-7$ R, TT199 R and TT212 R for $\mathrm{S} 2-1$, and S2-2 and the control groups. However, significant differences were determined in 0536R, 010018
$\mathrm{R}, 25712 \mathrm{R}, 62301 \mathrm{R}, 70352 \mathrm{R}, 7787-1 \mathrm{R}, 9947 \mathrm{R}, 9979 \mathrm{R}$, 9993R, 9997-7 R, TT119R, TT199R, TT212R, TT216R, TT317R and TT321R inbred lines when comparing S2-3 with the controls.

Statistically significant increases were determined in $\mathrm{DI}_{0} / \mathrm{RC}$ values of $01001 \mathrm{R}, 62301 \mathrm{R}, 9993 \mathrm{R}$, TT212R, TT317R and CL217R inbred lines from S3-2 and S3-2 drought stress groups at the milky seed stage when compared to the control groups. However, similarly to previous measurements of $\mathrm{DI}_{0} / \mathrm{RC}$ values, only about $37,5 \%$ decrease in $\mathrm{DI}_{0} / \mathrm{RC}$ values of $010018 \mathrm{R}$ restorer line were found significant at drought stress during the milky stage when comparing S3-3to S3-2 stage (Figure 3b).

$\mathrm{DI}_{0} / \mathrm{RC}$ parameter could be described as representative of the energy dissipation (DI) per excited reaction centre. $\mathrm{DI}_{0} / \mathrm{RC}$ rate could be increased related to higher inactive energy dissipation on RC. The dissipation could appear as heat, fluorescence or energy transfer (Strasser et al., 2000). However, the increase in $\mathrm{DI}_{0} / \mathrm{RC}$ indicates that the efficiency of the photosynthesis is reduced. TT 199 and TT $317 \mathrm{R}$ lines had higher resistance based on $\mathrm{DI}_{0} / \mathrm{RC}$ values under almost all treatments and sunflower growth stages.

\section{Changes in $F_{V} / F_{M}$ values of lines at vegetative, head formation and milky stages}

After drought stress treatments, there were observed statistically significant changes of $\mathrm{F}_{\mathrm{V}} / \mathrm{F}_{\mathrm{M}}$ parameter values, which is a measurement for photochemical activity and maximum photochemical efficiency of PSII, showing the potential effectiveness with which the absorbed photons are captured by PSII reaction centers (Schreiber et al., 1994). However, when stress groups were compared with their controls, the decreases in some genotypes were found significant at the vegetative stage (Figure 1c).

Comparing the $\mathrm{F}_{\mathrm{V}} / \mathrm{F}_{\mathrm{M}}$ values of restorer lines, with applied drought stress at head formation stage, with control groups were found significant changes except 25712 R,7887-1 R, 9987-R, TT216R, CL217 R for S2-1 stress group, while $F_{V} / F_{M}$ changes were significant for all genotypes fromS2-3drought stress group. Besides, changes in $\mathrm{F}_{\mathrm{V}} / \mathrm{F}_{\mathrm{M}}$ values were not found significant for $\mathrm{S} 2-2$ treatment for all inbred lines. On the other hand, when each of this group was compared with each other, the changes of $\mathrm{F}_{\mathrm{V}} / \mathrm{F}_{\mathrm{M}}$ values were statistically significant except $0536 \mathrm{R}$, 010018 R, 25712 R, 70352 R, 7887-1 R, 9947-R, 9993 R, TT119 R, TT321 R AND CL $217 \mathrm{R}$ for the S2-2 - S21couple; 62301 R, 6973 R, 7887-1 R, 8129 R, 9947 R, 9987 R, 9997-7 R, TT212 R, TT214 R, TT317 R and CL 217 R when compared S2-3 with S2-1; and except $01001 \mathrm{R}$ comparing S2-3 with S2-2.

Similarly, with previous measured traits, the changes in $\mathrm{F}_{\mathrm{V}} / \mathrm{F}_{\mathrm{M}}$ values of restorer lines exposed to drought stress at the milky seed stage were found significant except 62301R and TT212R inbred lines when comparing both S3-2 and S3-3 with their controls. (Figure 3c). Besides, change in $F_{V} / F_{M}$ values of $010018 R$, 62301R, 6973R, 78871R，9979R，9993R，9997-7R，TT212R，TT317R and 
TT321R lines were found significant when were compared S3-2with S3-3 stress group.

The $F_{V} / F_{M}$ parameter has begun to be used for detecting environmental stress (such as drought, salinity, heavy metal etc..) in plants. Recently, Oukarroum et al. (2007) and Zivcak et al. (2008) pointed out that the maximum quantum yield of primary photochemistry, $\mathrm{F}_{\mathrm{V}} / \mathrm{F}_{\mathrm{M}}$, has been generally insensitive to drought stress. Present results might support this statement.

\section{Changes in $P I_{a b s}$ of lines at vegetative, head formation and milky stages}

$\mathrm{PI}_{\mathrm{abs}}$ index is one the best parameter to screen genotypes with improved performance and grain production under drought stress. This index combines several parameters, as density of fully active RCs; the efficiency of electron movement by trapped exciton and the absorption of photon energy trapped by RCs, that describe three main functional characteristics of PSII reaction centre. $\mathrm{PI}_{a b s}$ is the quantitative information on the current state of plant performance under stress conditions (Strasser et al. 1999 and 2004; Tsimilli-Michael et al., 2000). Performance index $\left(\mathrm{PI}_{\mathrm{abs}}\right)$ decreased significantly in all genotypes at vegetative stage. Based on calculated $\mathrm{PI}_{\mathrm{abs}}$ values, it was shown that the changes at S1-2 level compared with S1-1 were significant except 6973R, 70352R, 9997-7R, TT214R and CL217R sunflower inbred lines (Figure 1d).

Comparing the $\mathrm{PI}_{\mathrm{abs}}$ values of sunflower inbred lines, subjected to drought stress at the head formation stage in the three stress groups - S2-1, S2-2 and S2-3, with each other, was observed significant differences between them except 010018R and TT321R. However, there were determined significant changes in inbred lines from S2-3 compared to S2-1 except 62301R, 8129R and TT214R (Figure 2d). Comparing the $\mathrm{PI}_{\mathrm{abs}}$ values of all the genotypes from the three stress groups demonstrated significant changes except 6973R, 7887-1R, 9979R, 9997-7R and 9987R T restorers from S2-2. -

Comparing the $\mathrm{PI}_{\mathrm{abs}}$ values of S3-3 with S3-2 stress groups of sunflower restorer lines subjected to drought stress at the milky stage only the changes of 62301R, 6973R, 70352R, 7887-1R, 9987R, TT212R, TT317R, TT321R and CL217R genotypes were found statistically significant (Figure 3d). On the other hand, when each stress group was compared with their controls were observed significant decreases in $\mathrm{PI}_{\mathrm{abs}}$ values of almost all inbred lines except TT212R restorer line for S3-2.

\section{Changes in $P I_{\text {total }}$ of lines at vegetative, head formation and milky stages}

Total performance index $\left(\mathrm{PI}_{\text {total }}\right)$ gives information about fluorescence energy absorption, the capture and conversion of the energy of the excitation, transformation of the excitation energy of the electron transport and the transmission of this energy to last electron acceptors at PS I (Strasser et al., 2010). In the drought period after emergence, the changes in $\mathrm{PI}_{\text {total }}$ values of sunflower inbred lines at the S1-1 stage, compared to S1-2 stage were found statistically significant, except 01001R, 010018R, 62301R, 8129R and TT119R inbred lines. On the other hand, the highest decreases in $\mathrm{PI}_{\text {total }}$ values were determined in the 0536R and 70352R inbred lines (Figure 1e). Similarly, except $0536 \mathrm{R}$ and $70352 \mathrm{R}$ male lines in $\mathrm{S} 1-1, \mathrm{PI}_{\text {total }}$ values of all genotypes were lowered significantly in S1-1 and S12 comparing with their controls.

The decreases in the $\mathrm{PI}_{\text {total }}$ values of all control plant genotypes in the period of head formation stage were detected. At the head formation stage under stress treatments; all changes in the $\mathrm{PI}_{\text {total }}$ values of restorer lines were generally found statistically significant when compared: S2-3 with S2-2 except 010018R; S2-3 with S21 except 01001R; and S2-2 with S2-1 except 62301R, 70352R and 9997-7R lines (Figure 2e). Furthermore, statistically significant changes in the $\mathrm{PI}_{\text {total }}$ values were also detected comparing all the stress treatments with their controls.

The decreases in $\mathrm{PI}_{\text {total }}$ of lines exposed to drought stress at the milky seed stage were found significant in all genotypes. At the milky seed stage, when comparing S3-3 to S3-2 stress group were demonstrated significant changes in $\mathrm{PI}_{\text {total }}$ values in only $62301 \mathrm{R}, 9987 \mathrm{R}, 70352 \mathrm{R}, 9987 \mathrm{R}$, TT212R, TT317R, TT321R and TT317R restorer lines (Figure 3e). Furthermore, changes in $\mathrm{PI}_{\text {total }}$ values of sunflower lines were found significant in both drought stress treatments when each of them was compared with their controls. 
$\mathbf{a}$

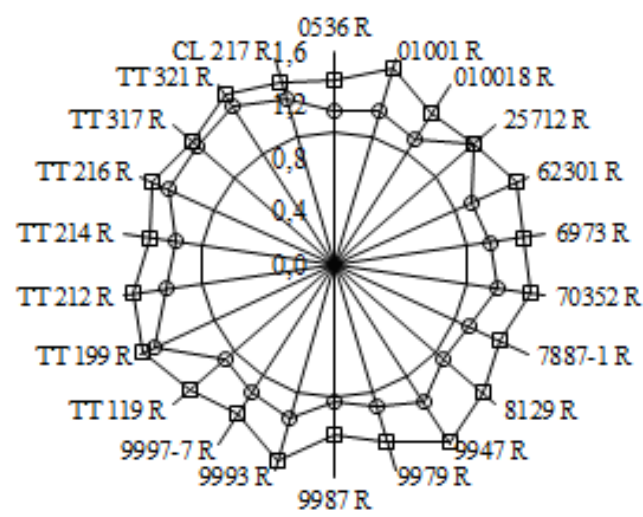

$\mathbf{c}$

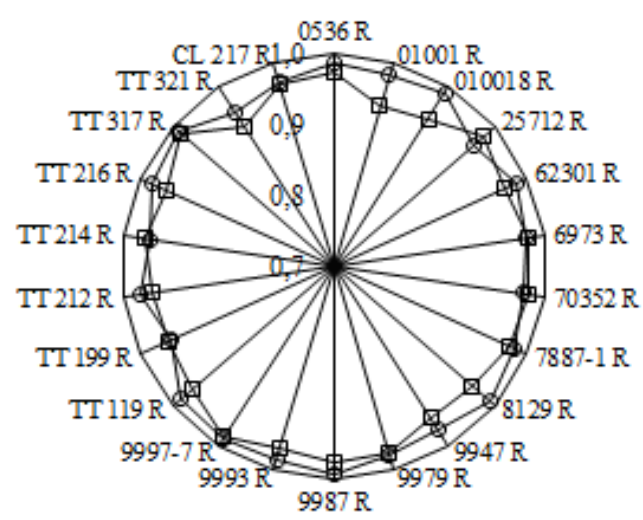

b
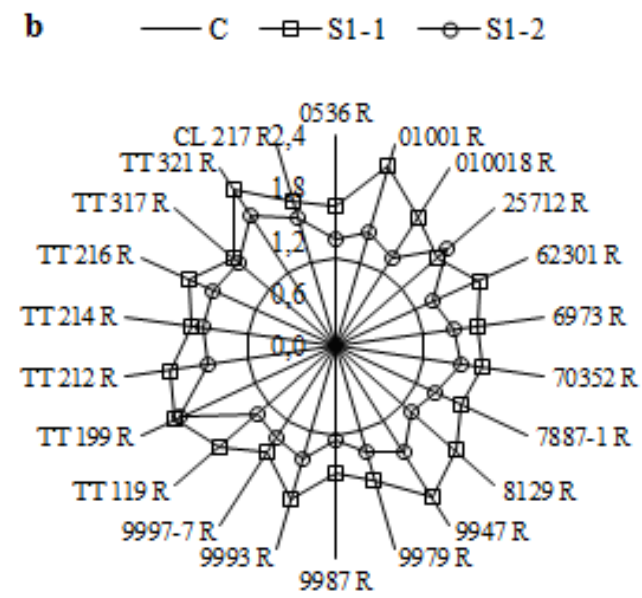

d $\longrightarrow \mathrm{C} \rightarrow \mathrm{S} 1-1-\mathrm{S} 1-2$

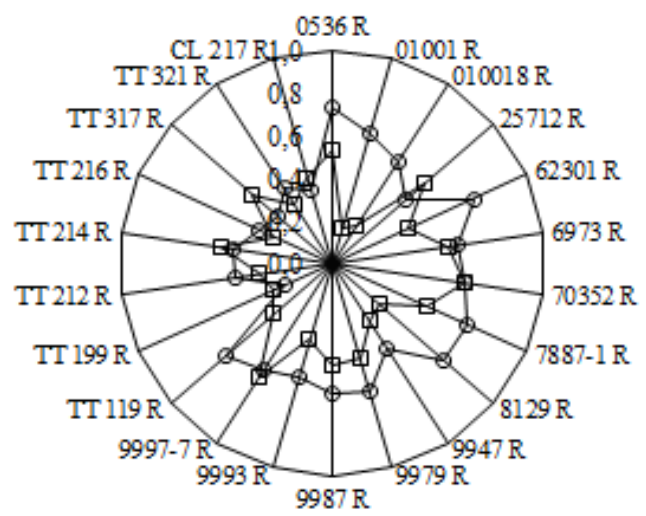

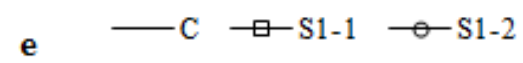

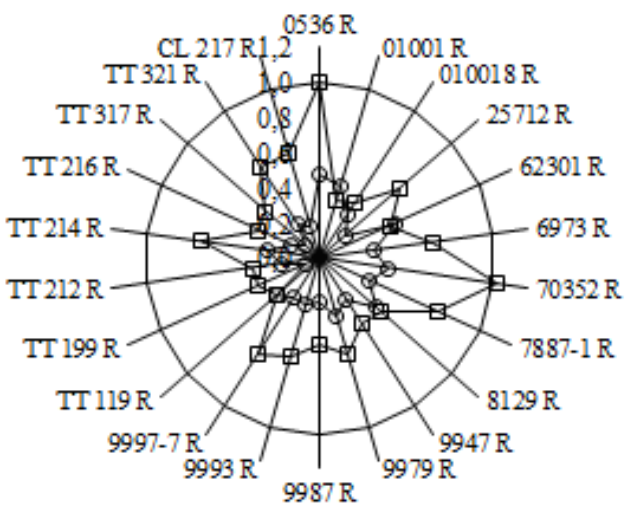

Figure 1. The effect of drought stress treatments on effective antenna size of an active RC (a, ABS/RC; LSD: 0.083), dissipation per $\mathrm{RC}$ (b, DI $/$ RC; LSD: 0.0185), the maximum quantum efficiency of PS II (c, FV/FM; LSD: 0.0067) and performance indexes (d and e,

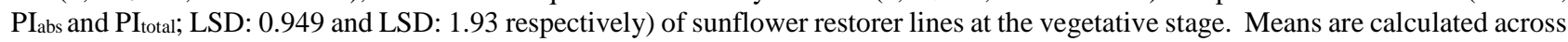
each treatment of all the sunflower genotypes and the values normalized by the values of the control plants (control value: 1) for each genotypes. 
$\mathbf{a}$

$\longrightarrow \mathrm{C} \rightarrow \mathrm{S} 2-1 \rightarrow \mathrm{S} 2-2 \rightarrow \mathrm{S} 2-3$

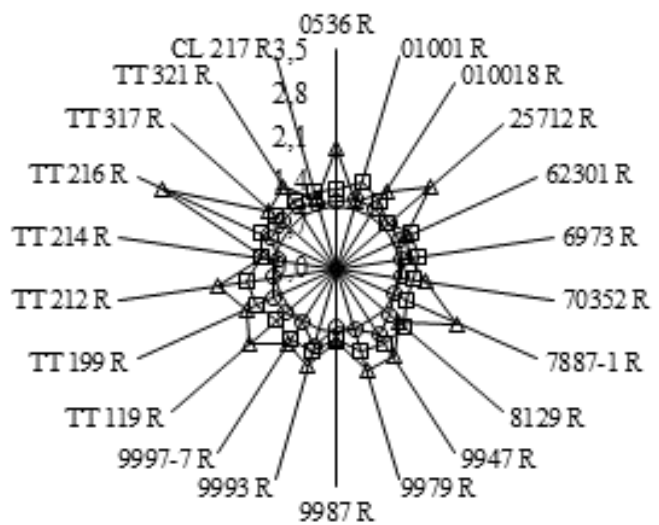

c

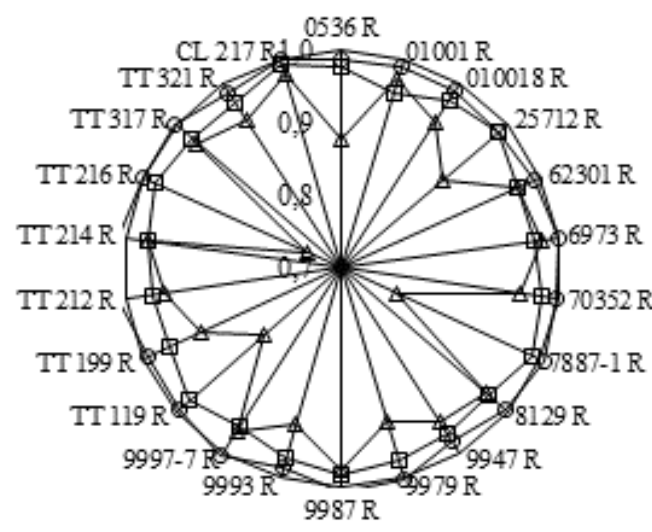

b

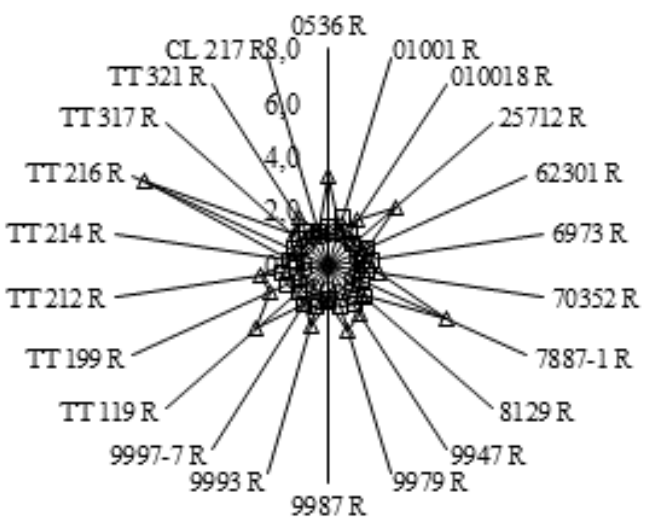

d $-\mathrm{C} \rightarrow \mathrm{S} 2-1 \multimap \mathrm{S} 2-2 \rightarrow \mathrm{S} 2-3$

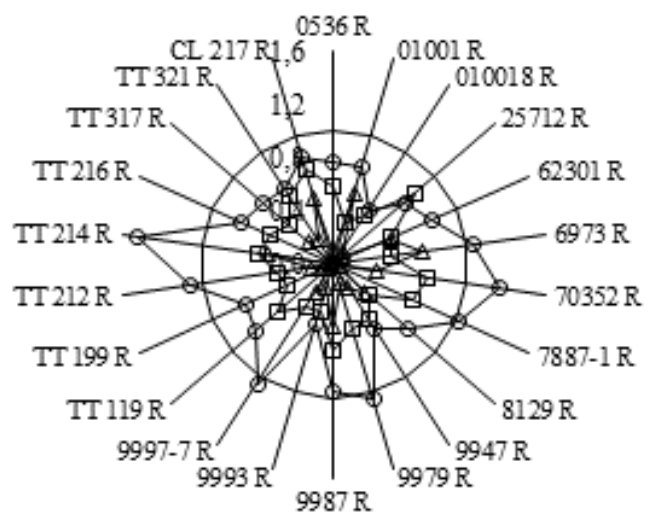

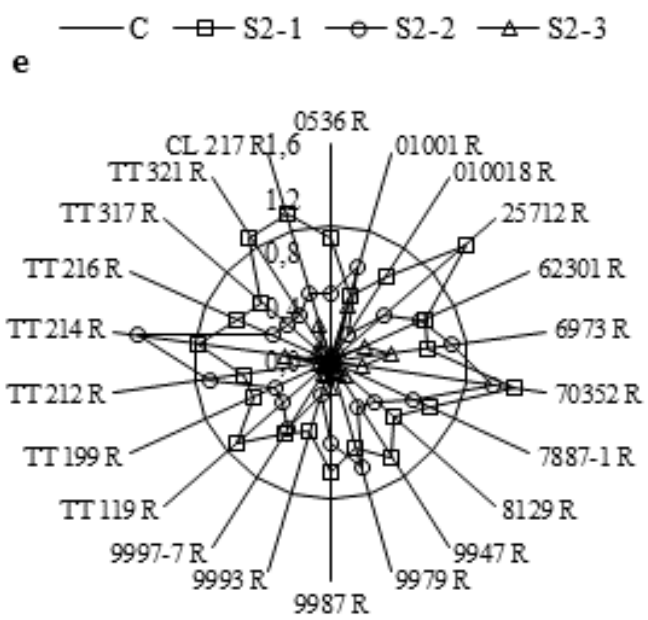

Figure 2. The effect of drought stress treatments on effective antenna size of an active RC (a, ABS/RC; LSD: 0.144), dissipation per RC (b, DIo/RC; LSD: 0.928), the maximum quantum efficiency of PS II (c, Fv/FM; LSD: 0.0177) and performance indexes (d and e, PIabs and PItotal; LSD: 0.89 and LSD: 1.93 respectively) of sunflower restorer lines at the head formation stage. Means are calculated across each treatment of all the sunflower genotypes and the values normalized by the values of the control plants (control value: 1) for each genotypes. 

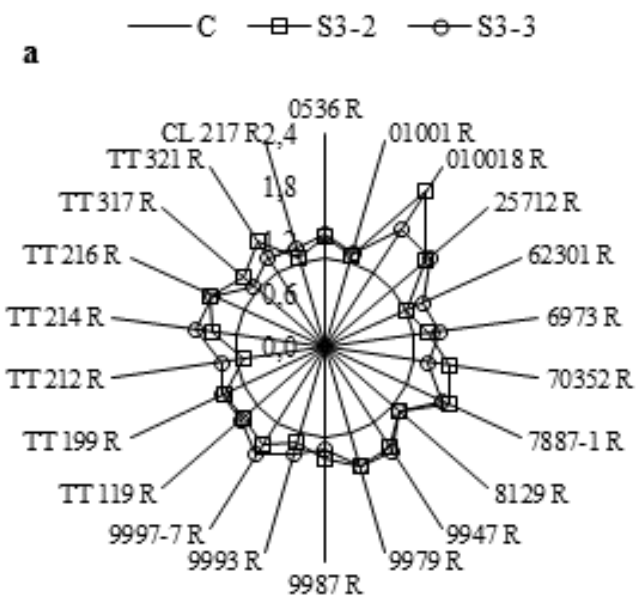

c

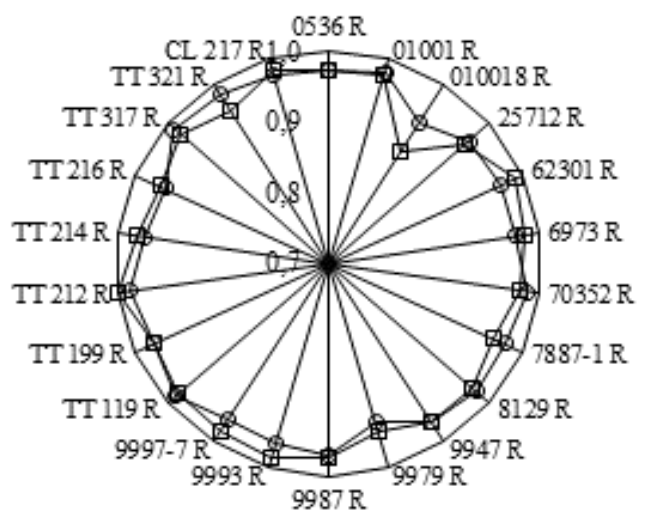

b

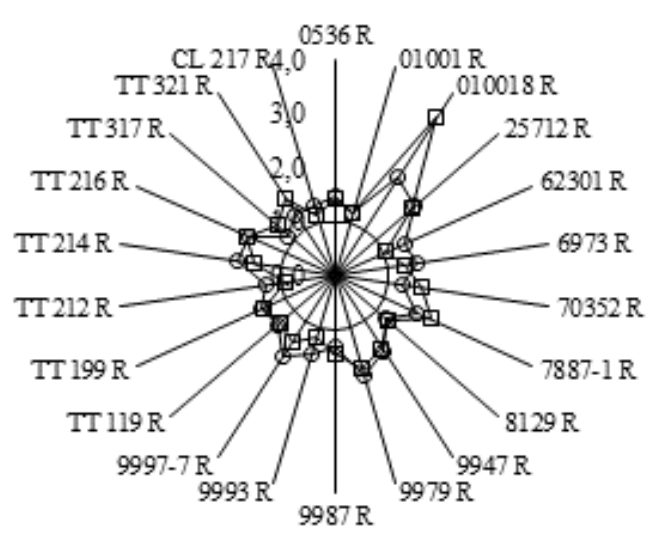

d

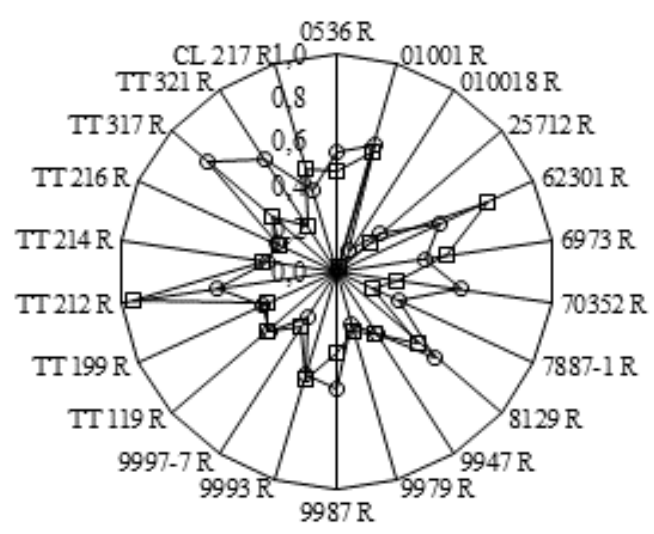

e
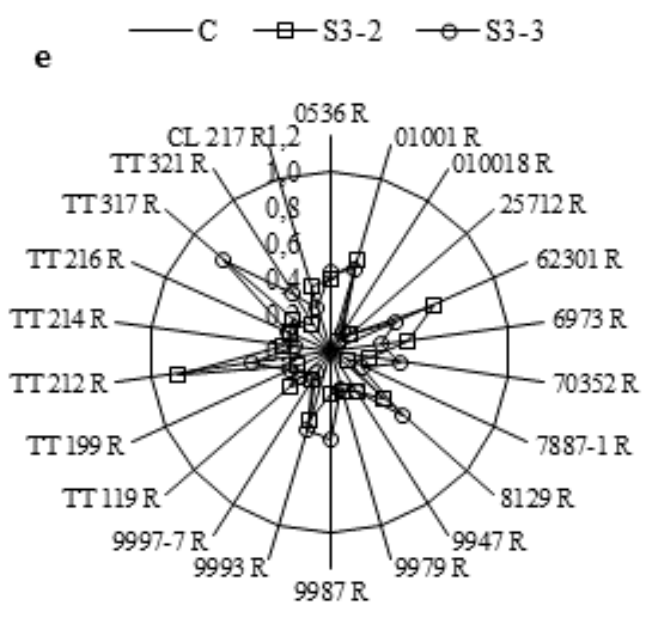

Figure 3. The effect of drought stress treatments on effective antenna size of an active RC (a, ABS/RC; LSD: 0.13), dissipation per RC (b, DI $/$ RC; LSD: 0.0413), the maximum quantum efficiency of PS II (c, $\mathrm{FV}_{\mathrm{V}} / \mathrm{F}_{\mathrm{M}}$; LSD: 0.0101) and performance indexes (d and e, $\mathrm{PI}_{\text {abs }}$ and $\mathrm{PI}_{\text {total }}$; LSD: 1.120 and LSD: 1.518 respectively) of sunflower restorer lines at the milky seed stage. Means are calculated across each treatment of all the sunflower genotypes and the values normalized by the values of the control plants (control value: 1) for each genotypes. 
In conclusion, performance indexes $\left(\mathrm{PI}_{\mathrm{abs}}\right.$ and $\left.\mathrm{PI}_{\text {total }}\right)$ are very sensitive and reliable tools for drought tolerance screening of different crops and in most of the experimental stress conditions (Strasser et al. 2000; Oukarroum et al. 2007; Öz et al., 2014; Çiçek et al., 2015) which is in accordance with our results obtained in the current study. Based on the polyphasic chlorophyll $a$ fluorescence results, 70352 R (the most tolerant), 8129 R, 0536 R, 9947 R, 6973
$\mathrm{R}, 9993 \mathrm{R}$ and CL217 R were determined as drought tolerant restorer inbred lines, whereas TT $317 \mathrm{R}$, TT $199 \mathrm{R}$ (the most sensitive), TT $216 \mathrm{R}, 01001 \mathrm{R}, 9987 \mathrm{R}$ restorer lines as drought sensitive inbred lines (Table 3). The conclusions made about the restorer lines, that were determined to be the most drought tolerant in the present study, are in agreement with our previous researches (Pekcan et al., 2015a, b and c, and Pekcan et al., 2016).

Table 3. The drought tolerance sorting of sunflower male inbred lines using Drought Factor Index (DFI) and Damage Index (DI) calculated by performance indexes

\begin{tabular}{|c|c|c|c|c|c|c|c|c|c|c|c|c|c|c|}
\hline \multicolumn{15}{|c|}{ Scores } \\
\hline & \multicolumn{4}{|c|}{ S1 } & \multicolumn{4}{|c|}{ S2 } & \multicolumn{4}{|c|}{ S3 } & \multirow[b]{2}{*}{ Total } & \multirow[b]{2}{*}{ \# } \\
\hline Lines & $\begin{array}{c}\text { DFI } \\
\text { PI }_{\text {total }}\end{array}$ & $\begin{array}{l}\text { DFI- } \\
\text { PI }_{\text {abs }}\end{array}$ & $\begin{array}{c}\text { DI- } \\
\text { PI }_{\text {abs }}\end{array}$ & $\begin{array}{c}\text { DI- } \\
\text { PI }_{\text {total }}\end{array}$ & $\begin{array}{l}\text { DFI- } \\
\text { PI }_{\text {total }}\end{array}$ & $\begin{array}{l}\text { DFI- } \\
\text { PI }_{\text {abs }}\end{array}$ & $\begin{array}{l}\text { DI- } \\
\text { PI }_{\text {abs }}\end{array}$ & $\begin{array}{c}\text { DI- } \\
\text { PI }_{\text {total }}\end{array}$ & $\begin{array}{l}\text { DFI- } \\
\text { PI }_{\text {total }}\end{array}$ & $\begin{array}{l}\text { DFI- } \\
\text { PI }_{\text {abs }}\end{array}$ & $\begin{array}{c}\text { DI- } \\
\text { PI }_{\text {abs }}\end{array}$ & $\begin{array}{c}\text { DI- } \\
\text { PI }_{\text {total }}\end{array}$ & & \\
\hline $70352 \mathrm{R}$ & 18 & 18 & 35 & 38 & 21 & 20 & 61 & 60 & 18 & 18 & 31 & 33 & 371 & 1 \\
\hline $8129 \mathrm{R}$ & 22 & 21 & 25 & 29 & 16 & 16 & 33 & 36 & 22 & 21 & 35 & 38 & 314 & 2 \\
\hline $0536 \mathrm{R}$ & 21 & 22 & 41 & 42 & 2 & 3 & 35 & 43 & 21 & 22 & 24 & 28 & 304 & 3 \\
\hline 9947 R & 16 & 13 & 20 & 25 & 19 & 21 & 40 & 45 & 16 & 13 & 34 & 35 & 297 & 4 \\
\hline $6973 \mathrm{R}$ & 14 & 17 & 25 & 26 & 18 & 18 & 47 & 51 & 14 & 17 & 17 & 17 & 281 & 5 \\
\hline 9993 R & 20 & 20 & 31 & 35 & 8 & 9 & 22 & 25 & 20 & 20 & 32 & 32 & 274 & 6 \\
\hline CL $217 \mathrm{R}$ & 7 & 5 & 13 & 21 & 22 & 22 & 49 & 51 & 7 & 5 & 33 & 31 & 266 & 7 \\
\hline TT $321 \mathrm{R}$ & 19 & 14 & 26 & 28 & 10 & 12 & 42 & 39 & 19 & 14 & 22 & 17 & 262 & 8 \\
\hline 7887-1 R & 13 & 16 & 31 & 28 & 11 & 6 & 46 & 37 & 13 & 16 & 22 & 21 & 260 & 9 \\
\hline $9979 \mathrm{R}$ & 15 & 15 & 25 & 26 & 13 & 14 & 43 & 39 & 15 & 15 & 15 & 18 & 253 & 10 \\
\hline $62301 \mathrm{R}$ & 17 & 19 & 29 & 28 & 12 & 10 & 27 & 25 & 17 & 19 & 22 & 20 & 245 & 11 \\
\hline TT $214 \mathrm{R}$ & 5 & 3 & 20 & 20 & 20 & 17 & 50 & 55 & 5 & 3 & 16 & 17 & 231 & 12 \\
\hline TT $212 \mathrm{R}$ & 9 & 10 & 17 & 15 & 7 & 8 & 29 & 34 & 9 & 10 & 29 & 30 & 207 & 13 \\
\hline $010018 \mathrm{R}$ & 10 & 6 & 18 & 21 & 17 & 19 & 31 & 33 & 10 & 6 & 13 & 21 & 205 & 14 \\
\hline TT $119 \mathrm{R}$ & 11 & 12 & 18 & 16 & 3 & 2 & 23 & 34 & 11 & 12 & 27 & 23 & 192 & 15 \\
\hline 9997-7 R & 8 & 11 & 23 & 19 & 15 & 15 & 27 & 22 & 8 & 11 & 16 & 11 & 186 & 16 \\
\hline $9987 \mathrm{R}$ & 6 & 9 & 23 & 16 & 9 & 11 & 32 & 23 & 6 & 9 & 17 & 20 & 181 & 17 \\
\hline $25712 \mathrm{R}$ & 3 & 8 & 24 & 24 & 4 & 4 & 35 & 36 & 3 & 8 & 15 & 11 & 175 & 18 \\
\hline $01001 \mathrm{R}$ & 12 & 7 & 17 & 15 & 14 & 13 & 20 & 15 & 12 & 7 & 19 & 17 & 168 & 19 \\
\hline TT $216 \mathrm{R}$ & 4 & 4 & 19 & 22 & 1 & 1 & 28 & 28 & 4 & 4 & 16 & 21 & 152 & 20 \\
\hline TT $199 \mathrm{R}$ & 2 & 1 & 11 & 8 & 6 & 5 & 24 & 19 & 2 & 1 & 24 & 19 & 122 & 21 \\
\hline TT $317 \mathrm{R}$ & 1 & 2 & 15 & 4 & 5 & 7 & 15 & 9 & 1 & 2 & 27 & 26 & 114 & 22 \\
\hline
\end{tabular}

\section{ACKNOWLEDGMENTS}

This study was supported by the Scientific and Technological Research Council of Turkey (TUBITAK) under the Project 1001-1130926.

\section{LITERATURE CITED}

Awais M., A. Wajid, A. Ahmad, M. F. Saleem, M. U. Bashır, U. Saeed, J. Hussain, M. H. ur-Rahman. 2015. Nitrogen fertılization and narrow plant spacing stimulates sunflower productivity. Turk. J. Field Crops. 20(1): 99-108.

Baloğlu M.C., M. Kavas, G. Aydın, H.A. Öktem and A.M. Yücel. 2012. Antioxidative and physiological responses of two sunflower (Helianthus annuus) cultivars under PEG-mediated drought stress. Turk. J. Bot. 36: 707-714.

Baker N.R. (1991). A possible role for photosystem II in environmental perturbations of photosynthesis. Physiol. Plant. 81: 563-570.

Ceccarelli, S., S. Grando and M. Baum. 2007. Participatory plant breeding in water-limited environments. Exp. Agr. 43:1-25.

Çiçek, N., Ö. Arslan, Ş. Çulha-Erdal, F. Eyidoğan, Y. Ekmekçi. 2015. Are the photosynthetic performance indexes and the drought factor index satisfactory selection criterion for stress? Fresen. Environ. Bull. 24(11c): 4190-4198.

Deng X., Z.A Hu, H.X. Wang, X.G. Wen and T.Y. Kuang. 2003. A comparison of photosynthetic apparatus of the detached leaves of the resurrection plant Boea hygrometrica with its non-tolerant relative Chirita heterotrichia in response to dehydration and rehydration. Plant Sci.165: 851-861.

Farooq M., A. Wahid, N. Kobayashi, D. Fujita, and S.M.A. Basra. 2009. Plant drought stress: effects, mechanisms and management. In: Sustainable Agriculture. Eds. Lichtfouse E., Navarrete M., Debaeke P., Souchère V., Alberola C., Millot, Dijon, Springer Press. France.

Faraloni C., I. Cutino, R. Petruccelli, A.R. Leva, S. Lazzeri and G. Torzillo. 2011. Chlorophyll fluorescence technique as a rapid tool for in vitro screening of olive cultivars (Olea europaea L.) tolerant to drought stress. Environ. Exp. Bot. 73: 49-56.

Ghaffari M., M. Toorci, M. Valizade and M.R. Shakiba. 2012. Morpho-physiological screening of sunflower inbred lines under drought stress condition. Turk. J. Field Crops. 17(2):185-190.

Gholinezhad E., R. Darvishzadeh and I. Bernousi. 2015. Evaluation of sunflower grain yield components under 
different levels of soil water stress in Azerbaijan. Genetika. 47(2): 581-598.

Glerum, C. 1985. Frost hardiness of coniferous seedlings: principles and applications. Ed. Duryea ML, Proc. of The Workshop "Evaluating seedling quality: principles, procedures, and predictive abilities of majortests". October 16-18. Corvallis (OR): Oregon State University, 107-123, Forest Research Laboratory.

Gul V. and K. Kara. 2015. Effects of different nitrogen doses on yield and quality traits of common sunflower (Helianthus annuus L.). Turk. J. Field Crops. 20(2): 159-165.

Guney E., M. Tan and H. Yolcu. 2012. Yield and quality characteristics of sunflower silages in highlands. Turk. J. Field Crops. 17(1): 31-34.

Hasanuzzaman M., K. Nahar, S.S. Gill and M. Fujita. 2014. Drought stress responses in plants, oxidative stress and antioxidant defense. Climate Change and Plant Abiotic Stress Tolerance. ed: Tuteja N. and Gill S.S.,VCH Verlag: Wiley.

Howell T.A., S.R. Evett, J.A. Tolk, K.S. Copeland and T.H Marek. 2015. Evapotranspiration, water productivity and crop coefficients for irrigated sunflower in the U.S. Southern High Plains. Agr. Water Manage. 162: 33-46.

Iqbal, N., M. Ashraf and M.Y. Ashraf. 2008. Glycinebetaine, an osmolyte of interestto improve water stress tolerance in sunflower (Helianthus annuus L.): water relations and yield. S. Afr. J. Bot. 74: 274-281.

Kalaji, M.H., A. Oukarroum, V. Alexandrov, M. Kouzmanova, M. Brestic, M. Zivcak, I.A Samborska, M.D. Cetner, S.I. Allakhverdiev and V. Goltsev. 2014. Identification of nutrient deficiency in maize and tomato plants by in vivo chlorophyll a fluorescence measurements. Plant Physiol. Biochem. 81: 1625 .

Karadoğan, T., I. Akgun and N. Altındal. 2009. Effect of leaf removal on sunflower yield and yield components and some quality characters. Turk. J. Field Crops. 14(2): 45-54.

Karam, F., R. Lahoud, R. Masaad, R. Kabalan, J. Breidi, C. Chalita and Y. Rouphael. 2007. Evapotranspiration, seed yield and water use efficiency of drip irrigated sunflower under full and deficit irrigation conditions. Agr. Water Manage. 90: 213-223.

Kaya, Y. 2014. Sunflower. Ed: Pratap A. and Kumar J., Alien Gene Transfer in Crop Plants 281-315. Springer Press.

Kaya, Y., I. Balalic and V. Miklic. 2015. Eastern europe perspectives on sunflower production and processing. In: Sunflower: Chemistry, Production, Processing, and Utilization. Ed. N. Dunford, E. M. Force. 710 p. 575-638. American Oil Chemistry Society (AOCS).

Kaya, Y. 2016. Sunflower. In: Breeding Oilseed Crops for Sustainable Production. Ed. S. Gupta, 55-88. $1^{\text {st }}$ Edition. Elseiver Press.

Langeroodi, A.R.S. 2015. Sunflower and soil response to seven years of tillage, residue management and nitrogen fertilizer. Turk. J. Field Crops. 20(2): 194-202

Murchie E.H. and T. Lawson. 2013. Chlorophyll fluorescence analysis: a guide to good practice and understanding some new applications. J. Exp. Bot. 64(13): 3983-3998.

Oukarroum, A., S. El Madidi, G. Schansker and R.J. Strasser. 2007. Probing the responses of barley cultivars $(H$. vulgare L.) by chlorophyll a fluorescence OLKJIP under drought stress and re-watering. Environ. Exp. Bot. 60: 438-446.

Oukarroum, A., G. Schansker and R.J. Strasser. 2009. Drought stress effects on photosystem I content and photosystem II thermotolerance analyzed using $\mathrm{Chl}$ a fluorescence kinetics in barley varieties differing in their drought tolerance. Physiol. Plant. 137:188-199.

Oukarroum, A., F. Bussotti, V. Goltsev and H.M. Kalaji. 2015. Correlation between reactive oxygen species production and photochemistry of photosystems I and II in Lemna gibba L. plants under salt stress. Environ. Exp. Bot. 109: 80-88.

Öz, M.T., Ö. Turan, C. Kayıhan, F. Eyidoğan, Y. Ekmekçi, M. Yücel and H.A. Öktem 2014. Evaluation of photosynthetic performance of wheat cultivars exposed to boron toxicity by the JIP fluorescence test. Photosynthetica. 52(4): 555-563.

Pekcan, V., G. Evci, M.I. Yilmaz, A.S. Balkan Nalcaiyi, Ş. Çulha Erdal, N. Cicek, Y. Ekmekci and Y. Kaya. 2015a. Drought tolerance of some sunflower inbred lines and effects on some yield traits. Agr. Forest. 61(4): 101-107.

Pekcan, V., G. Evci, M.I. Yilmaz, A.S. Balkan Nalcaiyi, Ş. Çulha Erdal, N. Cicek, Y. Ekmekci and Y. Kaya. 2015b. Evaluating foliar responses of sunflower genotypes under drought stress. Int. J. Sci. Res. Sci. Techno. 1(6): 54-63.

Pekcan, V., G. Evci, M.I. Yilmaz, A.S. Balkan Nalcaiyi, Ş. Çulha Erdal, N. Cicek, Y. Ekmekci and Y. Kaya. 2015c. Effects of drought on morphological traits of some sunflower lines. Proc. of 2. Int. Plant Breed. Con. 1-5 November, Antalya.

Pekcan, V., G. Evci, M.I. Yilmaz, A.S. Balkan Nalcaiyi, Ş. Çulha Erdal, N. Cicek, Y. Ekmekci and Y. Kaya. 2016. Effects of drought stress sunflower stems and roots. Proc. of Int. Confer. Che. Agr. Life Sci. (CALS-16) 4-5, February. Bali, Indonesia.

Pinheiro C. and M.M. Chaves. 2011. Photosynthesis and drought: can we make metabolic connections from available data? J. Exp. Bot. 62: 869-882.

Richards, R. A. 2006. Physiological traits used in the breeding of new cultivars for water-scarce environments. Agr. Water Manage. 80:197-211.

Schreiber, U., W. Bilger, and C. Neubauer. 1994. Chlorophyll fluorescence as a non-intrusive indicator for rapid assessment of in vivo photosynthesis. In: Ecophysiology of Photosynthesis. Eds. E.D Schulze and M.M. Caldwell. 49-70. Berlin: Springer-Verlag.

Shehzad M.A. and M. Maqsood. 2015. Integrated nitrogen and boron fertilization improves the productivity and oil quality of sunflower grown in a calcareous soil. Turk. J. Field Crops. 20(2): 213-222.

Sezener, V., H. Basal, C. Peynircioglu, T. Gurbuz and K. Kizılkaya. 2015. Screening of cotton cultivars for drought tolerance under field condition. Turk. J. Field Crops. 20(2): 223-232.

Strasser R.J., M. Tsimilli-Michael and A. Srivastava. 2004. Analysis of the fluorescence transient. In: Chlorophyll fluorescence: A Signature of Photosynthesis. Advances in Photosynthesis and Respiration Series. Eds. G. Papageorgiou and C. Govindjee. 321-362). Springer Press. Berlin.

Strasser, B.J. and R.J. Strasser. 1995. Measuring fast fluorescence transient to address environmental questions: the JIP-test. In: Photosynthesis: from light to biosphere. Ed. P., Mathis. 977980. Kluwer Academic Publisher, Dordrecht, The Netherlands.

Strasser, R. J., A. Srivastava and M. Tsimilli-Michael. 2000. The fluorescent transient as a tool to characterise and screen photosynthetic samples. In: Probing Photosynthesis: Mechanisms, Regulation and Adaptation. Eds. Yunus, M., Pathre, U., Mohanty, P. 445-483). Taylor and Francis Press, London.

Strasser R.J., M. Tsimilli-Michael and A. Srivastava. 2004. Analysis of the fluorescence transient. Ed: George C., Papageorgiou C. and Govindjee. Chlorophyll fluorescence: A Signature of Photosynthesis. Advances in Photosynthesis and Respiration Series. 321-362, Springer.

Strasser, R.J., M. Tsimilli-Michael, S. Qiang and V. Goltsev. 2010. Simultaneous in vivo recording of prompt and delayed fluorescence and 820-nm reflection changes during drying and after rehydration of the resurrection plant Haberlea rhodopensis. Biochim. Biophys. Acta. 1797 (6-7): 1313-1326. 
Strauss, A.J., G.H.J. Krüger, R.J. Strasser and P.D.R. Van Heerden. 2006. Ranking of dark chilling tolerance in soybean genotypes probed by the chlorophyll a fluorescence transient O-J-I-P. Environ. Exp. Bot. 56: 147-157.

Tsimilli-Michael, M., P. Eggenberg, B. Biro, K. Köve-Pechy, I. Vörös and R.J. Strasser. 2000. Synergistic and antagonistic effects of arbuscular mycorrhizal fungi and Azospirillum and Rhizobium nitrogen-fixers on the photosynthetic activity of alfalfa, probed by the polyphasic chlorophyll a fluorescence transient OJIP. Appl. Soil Eco. 15: 169-182.

Toker C. 2009. Creation ion accumulations in barely mutants exposed to drought and salinity. Turk. J. Field Crops. 14: 162169.
Toker, C. N. Mutlu, 2011. Breeding for abiotic stresses. In: Biology and Breeding of Food Legumes. Eds. Pratap, A. and J. Kumar. 241-261. CABI, Wallingford.

Toker, C. 2014. Mutagenesis for resistance to abiotic stresses: chickpea as model crop. In: Mutagenesis: Exploring Novel Genes and Pathways. Ed.Tomlekova, N.B, Kozgar, M.I. and M.R. Wani. 215-238. Wageningen Academic Publishers, Wageningen,

Yıldırım I., H. Turhan and B. Özgen. The effects of head rot disease (Rhizopus stolonifer) on sunflower genotypes at two different growth stages. Turk. J. Field Crops. 15(1): 94-98.

Zivcak, M., M. Brestic, K. Olsovska and P. Slamka. 2008. Performance index as a sensitive indicator of water stress in Triticum aestivum L. Plant, Soil Environ. 54(4): 133-139. 